\title{
Immunotoxicological, biochemical, and histopathological studies on Roundup and Stomp herbicides in Nile catfish (Clarias gariepinus)
}

\author{
Gihan G. Moustafa, F. E. Shaaban, A. H. Abo Hadeed, and Walaa M. Elhady \\ Department of Forensic Medicine and Toxicology, Faculty of Veterinary Medicine, Zagazig University, Alzeraa Street Postal \\ Code 44511, Zagazig City, Sharkia Province, Egypt. \\ Corresponding author: Gihan G. Moustafa, e-mail: gihan292@hotmail.com, \\ FES: mahmoudnasr292@hotmail.com, AHAH: alidido@hotmail.com,WME: drwalaaelhady@yahoo.com \\ Received: 10-02-2016, Accepted: 20-05-2016, Published online: 23-06-2016 \\ doi: 10.14202/vetworld.2016.638-647 How to cite this article: Moustafa GG, Shaaban FE, Hadeed AHA, Elhady WM (2016) \\ Immunotoxicological, biochemical, and histopathological studies on Roundup and Stomp herbicides in Nile catfish (Clarias \\ gariepinus), Veterinary World, 9(6): 638-647.
}

\begin{abstract}
Aim: The current study was directed to investigate the immunotoxic and oxidative stress effects of Roundup and Stomp herbicides and their combination on Nile catfish (Clarias gariepinus).

Materials and Methods: The experiment was carried out on 120 fish that randomly divided into four equal groups with three replicates: The first group kept as control, the second group exposed to $1 / 296 \mathrm{~h}$ lethal concentration $50\left(\mathrm{LC}_{50}\right)$ of Roundup, the third group exposed to $1 / 296 \mathrm{~h} \mathrm{LC}_{50}$ of Stomp, and the fourth one exposed to a combination of Roundup and Stomp at previously-mentioned doses. The experiment was terminated after 15 days; blood samples were obtained at $1^{\text {st }} 8^{\text {th }}$, and $15^{\text {th }}$ days of treatment where the sera were separated for estimation of antioxidant enzymes. Meanwhile, at $15^{\text {th }}$ day of exposure part of blood was collected from all groups with an anticoagulant for evaluation of phagocytic activity, then the fish were sacrificed, and specimens from the liver of all groups were obtained for histopathological examination.
\end{abstract}

Results: Our results indicated that both herbicides either individually or in combination elucidated significant decrease in phagocytic activity that was highly marked in group exposed to both herbicides. Furthermore, our data elicited an obvious elevation in the levels of superoxide dismutase (SOD), catalase (CAT), and glutathione peroxidase (GPx). Meanwhile, the data depicted reduction in levels of reduced glutathione (GSH) and glutathione-S-transferase (GST). Histopathological investigation of liver proved the aforementioned results.

Conclusion: It could be concluded that either Roundup or Stomp alone cause significant deleterious effects on aquatic vertebrates. However, the use of their combination enhanced their toxic effects. Toxicity can end up in humans through the food chain.

Keywords: antioxidant enzymes, fish, phagocytosis, Roundup, Stomp.

\section{Introduction}

Worldwide, pesticide use has increased dramatically over the past two decades [1]. Pesticides have become some of the most frequently occurring organic pollutants of agricultural soils, ground and surface water, causing ecological imbalances [2] that may have toxicological effects on natural ecosystems, especially aquatic systems [3]. They cause damage to non-target organisms including fish [4]. The runoff of pesticides (insecticides, herbicides, and fungicides) from agricultural lands is a key concern for the health of aquatic organisms [5].

Herbicides are actively used in terrestrial and aquatic ecosystems to control unwanted weeds, and their use has generated serious concerns about the potential adverse effects of these chemicals on the environment and human health [6]. They are the

Copyright: Moustafa, et al. Open Access. This article is distributed under the terms of the Creative Commons Attribution 4.0 International License (http://creativecommons.org/licenses/ by/4.0/), which permits unrestricted use, distribution, and reproduction in any medium, provided you give appropriate credit to the original author(s) and the source, provide a link to the Creative Commons license, and indicate if changes were made. The Creative Commons Public Domain Dedication waiver (http:// creativecommons.org/publicdomain/zero/1.0/) applies to the data made available in this article, unless otherwise stated. most widely used chemicals in agriculture as they are account for about $40 \%$ of the pesticides volume used worldwide. Roundup is one of the most common herbicides used in agriculture and also used in forestry and horticulture including home use [7]. Moreover, it is being the most popular and widely used herbicide in most parts of the world [8]. The indiscriminate use of Roundup associated with careless handling, accidental spillage, or discharge of untreated effluents into natural waterways has caused harmful effects on aquatic life and may have contributed to long-term biological effects [9].

Stomp is liquid emulsive herbicide of the dinitroaniline type; its active ingredient is pendimethalin [10]. Pendimethalin is highly toxic to fish and aquatic invertebrates [11].

Reactive oxygen species (ROS) generation is continuously produced in biological systems either as side products of aerobic metabolism or products of specialized systems designed to produce ROS [12]. Perez et al. [13] examined the effects of three widely used pesticides that have been widely detected in aquatic systems, in which they found that binary mixtures elicited synergistic responses; however, aquatic organisms are rarely exposed to only one single contaminant but 
typically to mixtures of numerous pesticides with varying constituents in varying concentrations and concentration ratios. Biochemical markers, such as lipid peroxidation (LPO) and antioxidant enzymes, are widely used to assess the toxic stress, integrity of the immune system, and tissue damage in different organisms [14].

Although there is a considerable amount of information available on toxicity of individual herbicides to fish and aquatic invertebrates, there is less information on toxicity of herbicide mixtures to these organisms. Furthermore, the impacts of Stomp in fish have so far undergone little research, and there is still a great need to properly assess the impact of Stomp on fish. Therefore, the present work was conducted to shed some light on the hazardous effects of Roundup- and Stomp-based herbicides and their combination on Nile catfish (Clarias gariepinus).

\section{Materials and Methods \\ Ethical approval}

All animal-related procedures were carried out in accordance with the Ethical Committee of Zagazig University.

\section{Fish and experimental design}

A total number of 120 Nile catfish (C. gariepinus) with a body weight ranged from 90 to $115 \mathrm{~g}$ were used. Fish were obtained from the ponds of the Central Laboratory of Aquaculture Research, Abbassa, Abou-Hammad, Sharkia, Egypt. Fish were apparently healthy and free from skin lesions or external parasites; they were maintained in glass aquaria $(50 \times 40 \times 150 \mathrm{~cm}$ capacity) having $180 \mathrm{~L}$ of dechlorinated tap water. Each aquarium provided with aerator, thermostatically controlled with heater and thermometer. Fish were acclimatized for 2 weeks to the laboratory environment. Fish were fed 3 times daily on a basal diet contained $35.4 \%$ crude protein (from Hendrix Co.) The amount of food per day was $3 \%$ of fish body weight. The experiment was conducted for 2 weeks.

The fish were divided into four equal groups: The first group kept as control, the second group exposed to $1 / 296 \mathrm{~h}$ lethal concentration $50\left(\mathrm{LC}_{50}\right)$ of Roundup $(14.5 \mathrm{mg} / \mathrm{L})[15]$, whereas the third one exposed to $1 / 296 \mathrm{~h} \mathrm{LC}_{50}$ of Stomp $(420 \mu \mathrm{g} / \mathrm{L})$ [16]. The fourth group exposed to a combination of $1 / 296 \mathrm{~h} \mathrm{LC}_{50}$ of both of Roundup and Stomp.

\section{Tested compounds}

\section{Roundup (glyphosate-based herbicide)}

It was obtained in a commercial form Roundup. It is containing $48 \%$ emulsion concentration (EC), obtained from Monsanto Agriculture Company, USA.

Empirical Formula: $\mathrm{C}_{3} \mathrm{H}_{8} \mathrm{NO}_{5} \mathrm{P}$

Chemical Formula: N- (phosphonomethyl) glycine.

State: Clear, viscous amber-colored solution.

\section{Stomp (pendimethalin-based herbicide)}

Stomp $^{\circledR}$, it is containing 50\% EC (BASF PLC), an orange-yellow liquid emulsive herbicide of the dinitroaniline type [17]. It contains the inert components
$(50 \%)$, as petroleum solvents (naphthalene and ethylene dichloride).

Empirical formula: $\mathrm{C}_{13} \mathrm{H}_{19} \mathrm{~N}_{3} \mathrm{O}$.

Chemical formula: [n-(1-ethylpropyl)-3,4dimethyl-2,6-dinitrobenzenamine].

State: Orange-yellow solution.

\section{Sampling and measurements}

Blood samples were obtained at $1^{\text {st }}, 8^{\text {th }}$, and $15^{\text {th }}$ days of treatment; blood samples were collected from the caudal blood vessel [18] using sterile syringes, which was left to be clotted at room temperature followed by centrifugation at $3000 \mathrm{rpm}$, for $15 \mathrm{~min}$ for serum separation for biochemical studies, another part of blood at $15^{\text {th }}$ day of exposure was collected in glass tubes containing 10\% ethylenediaminetetraacetic acid (EDTA) solution and centrifuged at $3000 \mathrm{rpm}$ for $30 \mathrm{~min}$. The plasma was removed completely followed by separation of leukocytes for evaluation of phagocytic activity, and then fish were sacrificed by decapitation and dissected. Specimens from livers of the treated and control groups were obtained and preserved in 10\% neutral-buffered formalin for histopathological examination.

\section{Immunotoxic study}

Chemicals used for studying the phagocytic activity

1. Microbial strain: Candida albicans was kindly supplied by the Department of Bacteriology, Mycology and Immunity, Faculty of Veterinary Medicine, Zagazig University. It was used in a concentration of $5 \times 10^{6} \mathrm{CFU} / \mathrm{ml}$.

2. Culture media:

A. Sabouraud's dextrose agar

Media used for isolation and cultivation of C. albicans. This media was prepared according to the method described by Cruickshank et al. [19]. The ingredients were dissolved in distilled water at $121^{\circ} \mathrm{C}$ for $15 \mathrm{~min}$. after being autoclaved and cooled to $45^{\circ} \mathrm{C}$, chloramphenicol was added at concentration of $100 \mathrm{mg} / \mathrm{L}$ to the medium, $\mathrm{pH}$ was adjusted to be around 5 .

B. Roswell Park Memorial Institute 1640 medium (RPMI 1640) with 1-glutamine

The medium was obtained from GIBCO limited, UK, in a sterile patent preparation. The $\mathrm{pH}$ was adjusted to 7.2 by adding $2 \mathrm{~g} / \mathrm{L}$ sodium bicarbonate. This medium was used for leukocytes cultivation.

3. Buffers

A. Phosphate-buffered saline (PBS)

PBS was prepared according to the method described by Cruickshank et al. [19]. The PBS $\mathrm{pH}$ was adjusted to 7.0 and the sterilized by autoclaving at $121^{\circ} \mathrm{C}$ for $15 \mathrm{~min}$. This buffer was used for anticoagulant preparation, cell washing, and for serial dilution in killing assay.

B. Anticoagulant buffer

EDTA solution (10\%) in distilled water; it was used as 1:5 volumes of blood. 
Evaluation of phagocytic activity by Wilkinson [20], Lucy and Lary [21]

1. Preparation of Hank's balanced salt solution (HBSS) [19].

2. Preparation of $C$. albicans for determining the phagocytic activity

C. albicans was grown on Sabouraud's $2 \%$ dextrose broth for $48 \mathrm{~h}$ at $37^{\circ} \mathrm{C}$ to obtain the organism in the yeast phase only. The cultures were spinned at $1500 \mathrm{rpm}$ for $10 \mathrm{~min}$ and the deposit washed twice with PBS, and filtered through sterile gauze. The yeasts were resuspended in HBSS so as to give a concentration of $5 \times 10^{6} \mathrm{CFU} / \mathrm{ml}$.

The yeasts were killed by heating at $100^{\circ} \mathrm{C}$ in water bath for $30 \mathrm{~min}$. A large batch was prepared and divided into small aliquots sufficient for each test. These were stored at $-20^{\circ} \mathrm{C}$ until needed.

3. Preparation of leukocytes suspension for phagocytosis assay $[20,21]$.

a. Peripheral blood leukocytes suspension was prepared by sterile procedures

b. $2.5 \mathrm{ml}$ of blood were collected after 15 days of exposure and carefully layered on surface of Ficoll hypaque solution 1.077 density gradient equal volumes in sterile plastic tube

c. Centrifugation at $2400 \mathrm{rpm}$ for $30 \mathrm{~min}$ at $18-20^{\circ} \mathrm{C}$. The mononuclear cells form a white opaque band at Ficoll plasma interface. This layer was aspirated by sterile Pasteur pipette and placed in sterile plastic tube containing HBSS

d. The separated cells washed 3 times in HBSS at 2500, 1500, and $1000 \mathrm{rpm}$, respectively, each for $10 \mathrm{~min}$

e. Sedimented cells were suspended in $1 \mathrm{ml}$ of the RPMI media containing $1 \%$ fetal calf serum.

4. Preparation for phagocytosis assay

In sterile plastic tubes, put $0.25 \mathrm{ml}$ leukocyte suspension, $0.25 \mathrm{ml}$ heat-killed C. albicans, $0.25 \mathrm{ml}$ pooled serum, and $0.25 \mathrm{ml} \mathrm{HBSS}$.

The tubes were incubated at $37^{\circ} \mathrm{C}$ for $30 \mathrm{~min}$. They were centrifuged at $2500 \mathrm{rpm}$ for $5 \mathrm{~min}$, and the supernatant was removed with Pasteur pipette leaving a drop into which the sediment was resuspended. Smears were prepared from the deposit, dried in air, and stained with Leishman's stain.

\section{Evaluation of phagocytic activity}

Under a light microscope using oil immersion lens, 10 fields, each containing about 20 phagocytes, were examined. The total number of phagocytic cells and the number of phagocytes with ingested yeast cells in individual phagocytes were determined to calculate the percentage of phagocytosis and the phagocytic index (PI). The mean particle number associated with each cell represents the PI.

$$
\mathrm{PI}=\frac{\text { Total number of ingested yeast cells }}{\text { Total number of infected phagocytes }}
$$

The number of cells ingesting Candida represents the phagocytic percentage $(\mathrm{P} \%)$.

$$
\mathrm{P} \%=\frac{\begin{array}{c}
\text { Number of phagocytes with } \\
\text { ingested yeast cells }
\end{array}}{\text { Total number of phagocytes }} \times 100
$$

\section{Biochemical studies}

Determination of superoxide dismutase (SOD) activity according to the method described by Misra and Fridivich [22] and modified by Packer and Glazer [23], catalase (CAT) activity according to the method described by Sinha [24], reduced glutathione (GSH) according to the method described by Beutler [25] and modified by Beutler et al. [26], glutathione-S-transferase activity (GST) according to Habig et al. [27], and glutathine peroxidase activity (GPx) according to Puertas et al. [28].

\section{Histopathological study}

Histopathological examination of livers of control and treated groups that were collected and fixed in $10 \%$ buffered neutral formalin solution, dehydrated in gradual ethanol (70-100\%), cleared in xylene, and embedded in paraffin. $5 \mu$ thick paraffin sections were prepared, and then routinely stained with hematoxylin and eosin dyes according to Suvarna et al. [29], and then examined microscopically.

\section{Statistical analysis}

The obtained data were analyzed using the SPSS software, version 16 (SPSS Inc., Chicago, IL, USA). Groups' data were compared by one-way analysis of variance. The statistical significance was accepted at $(\mathrm{p}<0.05)$.

\section{Results}

Effect of Roundup and Stomp on phagocytic activity

The data illustrated in Table- 1 and Figure- 1 indicated the effect of Roundup and/or Stomp treatment on phagocytic activity of $C$. gariepinus leukocytes against

Table-1: Changes in phagocytic percent $(\mathrm{p} \%)$ and PI in C. gariepinus exposed to Roundup, Stomp, and both after 15 days of exposure (mean \pm SE) $(n=30)$.

\begin{tabular}{llcc}
\hline Group & Treatment & $\begin{array}{c}\text { Phagocytic } \\
\text { percent (p\%) }\end{array}$ & PI \\
\hline 1 & Control & $33.46 \pm 3.51^{\mathrm{a}}$ & $1.35 \pm 0.05^{\mathrm{a}}$ \\
2 & $1 / 2 \mathrm{LC}_{50}$ Roundup & $20.16 \pm 1.03^{\mathrm{b}}$ & $0.964 \pm 0.03^{\mathrm{b}}$ \\
3 & $1 / 2 \mathrm{LC}_{50}$ Stomp & $27.08 \pm 1.53^{\mathrm{a}}$ & $1.01 \pm 0.03^{\mathrm{b}}$ \\
4 & $1 / 2 \mathrm{LC}_{50}$ Roundup & $13.5 \pm 1.55^{\mathrm{c}}$ & $0.936 \pm 0.06^{\mathrm{b}}$ \\
& and $1 / 2$ LC $_{50}$ Stomp & & \\
\hline
\end{tabular}

Means within the same column having the different superscripts are significantly different at $(p<0.05)$.

$\mathrm{PI}=$ Phagocytic index, $\mathrm{SE}=$ Standard error, $\mathrm{LC}_{50}=$ Lethal concentration 50 


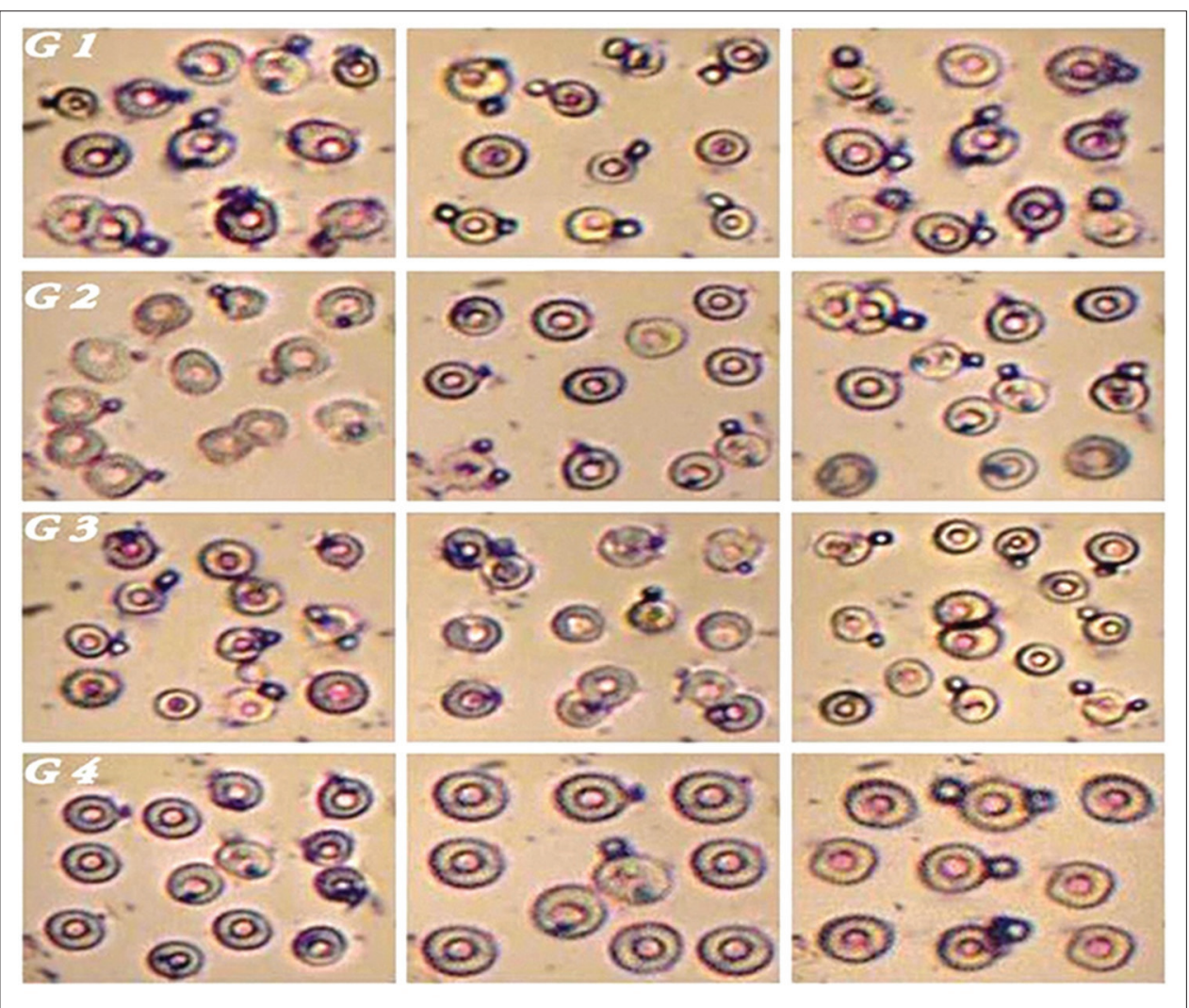

Figure-1: Photograph of phagocyte cells showing the effect of Roundup, Stomp, and both on phagocytic activity of Clarias gariepinus after 15 days of exposure. (G1) Phagocyte cells engulfing yeast cells in C. gariepinus of control group. (G2) Phagocyte cells showing destruction and inhibition of phagocytosis in group exposed to Roundup. (G3) Phagocyte cells showing destruction and inhibition of phagocytosis in group exposed to Stomp. (G4) Phagocyte cells showing severe destruction and inhibition of phagocytosis in group exposed to combination of Roundup and Stomp.

yeast cells at $15^{\text {th }}$ day of exposure. The phagocytic percent $(\mathrm{P} \%)$ was significantly reduced in the Rounduptreated group compared to the control one, while there was a non-significant decrease of the phagocytic percent in group treated with Stomp when compared with the control group. On the other hand, the phagocytic percent in group treated with both Roundup and Stomp showed an obvious significant decrease comparing with control group. In addition, the data illustrated clear significance difference between all treated groups when compared with each other. Regarding the PI, there was a significant decrease in all treated groups when compared to the control one.

\section{Effect of Roundup and Stomp on SOD and CAT activities}

Concerning the SOD activity in serum of C. gariepinus, our study showed a significant increase in fish exposed to the combination of both Roundup and Stomp at $1^{\text {st }}$ day of exposure. While there was no significant increase in fish exposed to Roundup or Stomp separately compared with the control group. At $8^{\text {th }}$ day of exposure, SOD activity increased significantly in fish exposed to Roundup, but there was no significant increase in the Stomp-treated group, while the increase in SOD activity was highly obvious in the combined treated group. Furthermore, the three treated groups depicted significance difference when compared with each other. Meanwhile, at $15^{\text {th }}$ day of exposure, the SOD activity elevated significantly in all treated groups compared to the control one (Table-2).

Regarding the CAT activity, the present study showed a significant elevation in fish exposed to Stomp while the elevation was obviously significant in groups exposed to Roundup and the combination of both herbicides comparing with the control group at $1^{\text {st }}$ day of exposure.

At $8^{\text {th }}$ day of exposure, fish exposed to Roundup or Stomp separately showed a significant increase in CAT activity, while the elevation was highly obvious in groups exposed to the combination of both herbicides comparing with the control group and also when comparing with Roundup and Stomp-treated groups. At $15^{\text {th }}$ day of exposure, the elevation in CAT activity was significant only in fish exposed to the combination of Roundup and Stomp, but there was no significant increase at other treated groups comparing with the control group (Table-2).

\section{Effect of Roundup and Stomp on the activities of reduced GSH, GST, and GPX}

Regarding the GSH level in serum of $C$. gariepinus, the current study demonstrated a significant decrease in Roundup exposed group and obviously significant decrease in the combined treated group at $1^{\text {st }}$ day of exposure compared to the control group, and also, there was significance difference in GSH level when comparing the treated groups with each other. 
While at $8^{\text {th }}$ and $15^{\text {th }}$ day of exposure the decrease in GSH level was significant in all treated groups when compared to the control one (Table-3).

Concerning the GST activity, no significant variations versus control were observed in all treated groups at $1^{\text {st }}$ day of exposure. At $8^{\text {th }}$ day of exposure, fish exposed to the combination of both Roundup and Stomp showed a significant reduction in GST activity, but there was no significant alteration in other treated groups comparing with control one. While at $15^{\text {th }}$ day of exposure, the reduction in GST activity was obvious in Roundup-treated group and highly obvious in group treated with the combination of both herbicides, besides, our data revealed that there was significance difference in GST level when comparing the three treated groups with each other, but no significant reduction was observed in Stomp-treated group compared to the control one (Table-3).

Regarding the GPx activity, fish exposed to Roundup showed a significant increase at all durations of exposure compared to the control one. In Stomp-treated group, the GPx activity showed a significant elevation at the $8^{\text {th }}$ day of exposure but did not show any significant elevation at other durations of exposure when compared with the control group. Fish exposed to the combination of both herbicides showed an obviously significant elevation compared to the control group in all durations of exposure (Table-3).

\section{Histopathological findings}

The liver of the control revealed normal hepatocytes and sinusoidal architectures (Figure-2a).
However, the liver of Roundup showed severe congestion in hepatoportal blood vessels (Figure-2b). Multifocal areas of coagulative necrosis invaded with numerous leukocytes and erythrocytes were visualized (Figure-2c). Severe hydropic degeneration and macrovesicular steatosis were detected (Figure-2d). The liver of Stomp showed moderate congestion, severe hydropic degeneration, and vacuolation in the hepatocytes (Figure-2e). The portal areas revealed periductal fibrosis and round cells infiltration besides hyalinization in the wall of blood vessels (Figure-2f). The reported lesions in both exposures to Roundup and Stomp were severe and represented by extensive coagulative necrosis and perivascular edema (Figure-2g). Intense interstitial and portal aggregations of round cells were noticed (Figure-2h).

\section{Discussion}

Aquatic environments are commonly impacted by various pesticides (including herbicides, fungicides, and insecticides) from different sources. Fish species are described as suitable monitors for the effects of noxious compounds because of their ecological and economical relevance [9]. In addition, changes at cellular and biochemical levels are among the most sensitive biological responses reported after fish exposure to aquatic pollutants [30].

The immune system of vertebrates, including that of fish, reacts with a particular sensitivity to xenobiotic exposure [31]. Phagocytic activity is a primitive defense mechanism and an important component of

Table-2: Changes in SOD and CAT activities of C. gariepinus exposed to Roundup, Stomp, and both at $1^{\text {st }}, 8^{\text {th }}$, and $15^{\text {th }}$ days of exposure (mean $\left.\pm S E\right)(n=30)$.

\begin{tabular}{|c|c|c|c|c|c|c|}
\hline \multirow[t]{2}{*}{ Parameters } & \multicolumn{3}{|c|}{ SOD (unit/mg protein) } & \multicolumn{3}{|c|}{ CAT $\left(\mu \mathrm{mol} \mathrm{H}_{2} \mathrm{O}_{2}\right.$ decomposed $\left./ \mathrm{ml}\right)$} \\
\hline & $1^{\text {st }}$ & $8^{\text {th }}$ & $15^{\text {th }}$ & $1^{\text {st }}$ & $8^{\text {th }}$ & $15^{\text {th }}$ \\
\hline Control & $40.26 \pm 1.16^{a}$ & $42.50 \pm 0.78^{a}$ & $44.35 \pm 2.85^{\mathrm{a}}$ & $28.38 \pm 2.75^{a}$ & $31.89 \pm 0.55^{a}$ & $44.63 \pm 1.20^{\mathrm{a}}$ \\
\hline $1 / 2$ LC $_{50}$ Roundup & $47.89 \pm 3.03^{a}$ & $52.60 \pm 1.65^{\mathrm{b}}$ & $51.57 \pm 1.54^{b}$ & $67.37 \pm 3.77^{c}$ & $49.16 \pm 3.60^{b}$ & $48.16 \pm 1.8^{\mathrm{ab}}$ \\
\hline $1 / 2$ LC $_{50}$ Stomp & $46.28 \pm 1.29^{a b}$ & $43.74 \pm 3.60^{\mathrm{a}}$ & $51.22 \pm 1.82^{b}$ & $47.03 \pm 0.31^{\mathrm{b}}$ & $44.71 \pm 1.83^{b}$ & $46.91 \pm 2.6^{a b}$ \\
\hline $\begin{array}{l}1 / 2 \text { LC }_{50} \text { Roundup } \\
\text { and } 1 / 2 \quad \text { LC }_{50} \text { Stomp }\end{array}$ & $52.03 \pm 3.60^{\mathrm{b}}$ & $60.44 \pm 0.25^{c}$ & $56.52 \pm 2.33^{b}$ & $69.50 \pm 1.46^{c}$ & $56.26 \pm 1.00^{c}$ & $51.98 \pm 1.3^{\mathrm{b}}$ \\
\hline
\end{tabular}

Means within the same column having the different superscripts were significantly different $(p<0.05)$. SOD=Superoxide dismutase, $\mathrm{CAT}=$ Catalase, $C$. gariepinus=Clarias gariepinus, $\mathrm{SE}=$ Standard error, $\mathrm{LC}_{50}=$ Lethal concentration 50

Table-3: Changes in GSH, GST, and GPx activities of $C$. gariepinus exposed to Roundup, Stomp, and both at $1^{\text {st }}$, $8^{\text {th }}$, and $15^{\text {th }}$ days of exposure (Mean $\left.\pm S E\right)(n=30)$.

\begin{tabular}{|c|c|c|c|c|c|c|c|c|c|}
\hline \multirow[t]{2}{*}{ Parameters } & \multicolumn{3}{|c|}{ GSH $(\mathrm{mg} / \mathrm{ml})$} & \multicolumn{3}{|c|}{ GST (U/I) } & \multicolumn{3}{|c|}{ GPx $(\mathrm{mU} / \mathrm{ml})$} \\
\hline & $1^{\text {st }}$ & $8^{\text {th }}$ & $15^{\text {th }}$ & $1^{\text {st }}$ & $8^{\text {th }}$ & $15^{\text {th }}$ & $1^{\text {st }}$ & $8^{\text {th }}$ & $15^{\text {th }}$ \\
\hline Control & $4.73 \pm 0.05^{a}$ & $4.44 \pm 0.25^{a}$ & $4.53 \pm 0.38^{a}$ & $0.39 \pm 0.017^{a}$ & $0.46 \pm 0.036^{a}$ & $0.45 \pm 0.02^{\mathrm{a}}$ & $19.42 \pm 0.73^{c}$ & $13.65 \pm 0.89 c$ & $11.39 \pm 0.53^{c}$ \\
\hline $\begin{array}{l}1 / 2 \mathrm{LC}_{50} \\
\text { Roundup }\end{array}$ & $3.28 \pm 0.50^{\mathrm{b}}$ & $2.75 \pm 0.33^{b}$ & $2.83 \pm 0.24^{b}$ & $0.31 \pm 0.012^{\mathrm{a}}$ & $0.35 \pm 0.03^{a}$ & $0.27 \pm 0.06^{b}$ & $23.19 \pm 0.53^{b}$ & $21.28 \pm 0.64^{b}$ & $21.89 \pm 0.86^{b}$ \\
\hline $\begin{array}{l}1 / 2 \mathrm{LC}_{50} \\
\text { Stomp }\end{array}$ & $4.39 \pm 0.31^{\mathrm{a}}$ & $2.84 \pm 0.30^{b}$ & $2.88 \pm 0.24^{b}$ & $0.35 \pm 0.08^{a}$ & $0.38 \pm 0.03^{a}$ & $0.38 \pm 0.02^{\mathrm{a}}$ & $20.97 \pm 0.49^{b c}$ & $20.80 \pm 0.87^{b}$ & $13.44 \pm 1.07^{c}$ \\
\hline $\begin{array}{l}1 / 2 \text { LC }_{50} \\
\text { Roundup } \\
\text { and } 1 / 2 \\
\mathrm{LC}_{50} \text { Stomp }\end{array}$ & $1.43 \pm 0.19^{c}$ & $2.06 \pm 0.36^{b}$ & $2.53 \pm 0.28^{b}$ & $0.30 \pm 0.017^{a}$ & $0.22 \pm 0.04^{b}$ & $0.14 \pm 0.03^{c}$ & $28.34 \pm 1.52^{\mathrm{a}}$ & $24.32 \pm 0.65^{a}$ & $28.23 \pm 2.55^{a}$ \\
\hline
\end{tabular}

Means within the same column having the different superscripts were significantly different $(p<0.05)$. $\mathrm{LC}_{50}=$ Lethal concentration 50, GSH=Reduced glutathione, GST=Glutathione-S-transferase activity, GPx=Glutathione peroxidase, C. gariepinus=Clarias gariepinus, $\mathrm{SE}=\mathrm{Standard}$ error 


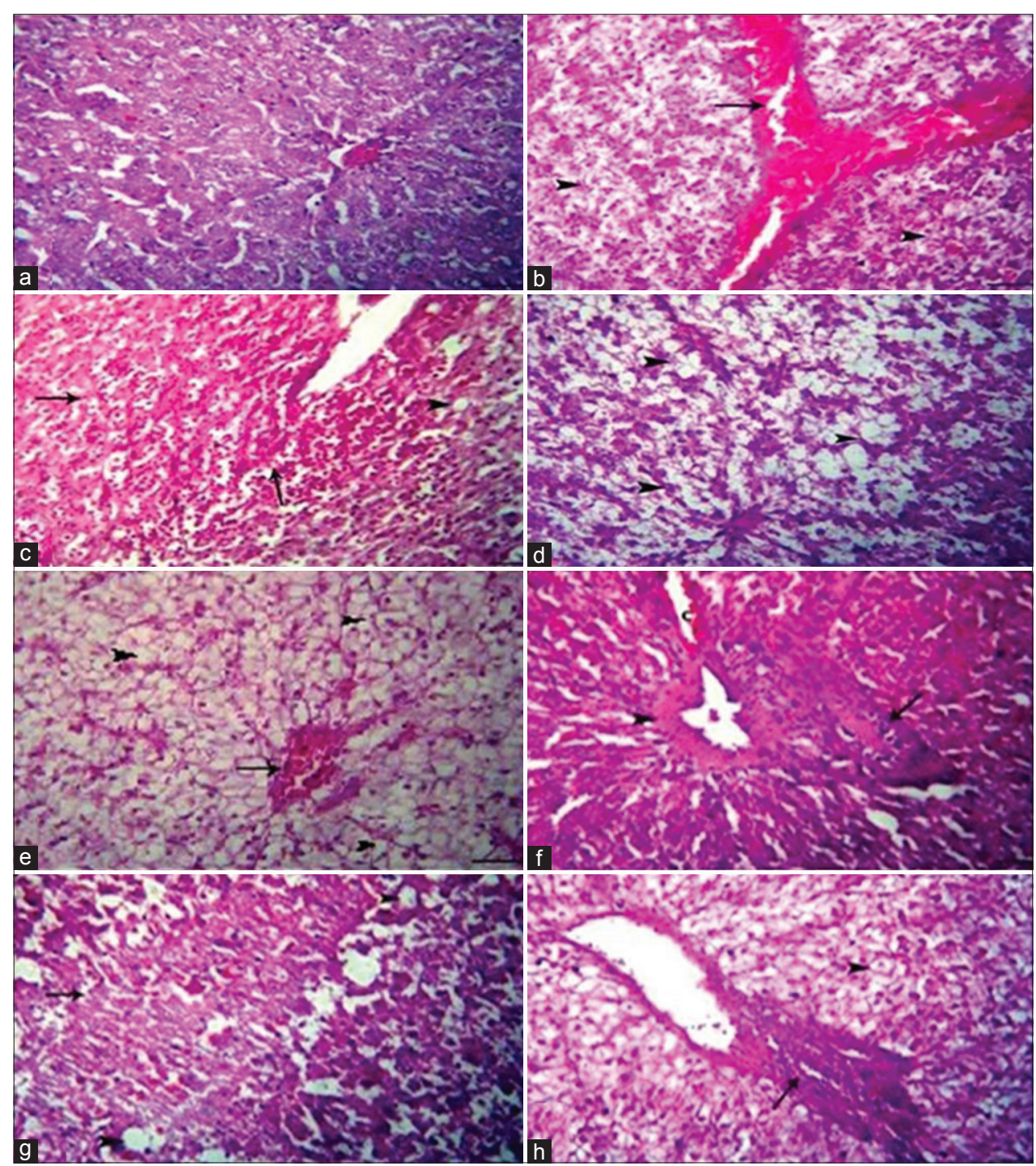

Figure-2: Liver from different groups: Control shows normal hepatocytes and sinusoidal architectures (a), Roundup shows severe congestion in hepatoportal blood vessels (arrow) (b), area of necrosis invaded with numerous leukocytes and erythrocytes (arrows) (c), and macrovesicular steatosis (d). Stomp shows congestion and severe hydropic degeneration and vacuolation in the hepatocytes (arrowheads) (e) and portal area with periductal fibrosis and round cells infiltration (arrow), and hyalinization in the wall of blood vessel (arrowhead) (f). Both Roundup and Stomp shows extensive coagulative necrosis (arrow) and perivascular edema $(\mathrm{g})$ and aggregation of round cells in the portal area (arrow) (h). Hematoxylin and eosin $\times$ Scale bar $=25 \mu \mathrm{m}$.

the non-specific immune system [32]. Phagocytosis is a response helpful to assess the immunological impact of environmental pollutants [33]. The obtained results revealed that the phagocytic activity was decreased significantly in Roundup and/or Stomp-treated fish. Our results concurred with those obtained by Kreutz et al. [34] in silver catfish exposed to $10 \%$ of the 96 h- $\mathrm{LC}_{50}$ glyphosate. A similar result was also observed in rainbow trout exposed to pendimethalin [35]. This decrease in phagocytic activity may be attributed to high soluble concentrations of herbicide disturb cell phagocytic activity. In fact, the membrane integrity of cells could be impaired by uptake of chemical compounds in organisms, which could interfere with the fluidity of cell membranes restricting the deformation of the membrane essential to the phagocytic endocytosis process [36] On the contrary of our result, Mohamed [37] studied the effect of the herbicide
Roundup on Biomphalaria alexandrina hemocytes and revealed a highly significant increase in the phagocytic activity that may lead to cytotoxic effects.

Matricon-Gondran and Letocart [38] speculated that these cytotoxic effects may be due to the changes in the sensitivity of intercellular adhesion molecules involved in the ingestion of foreign materials, resulting in increase of phagocytic activity.

Herbicides have the potential to introduce ROSs into biological systems, leading to oxidative stress on non-target organisms [39]. Fish, as many other vertebrates, are endowed with defensive mechanisms to counteract the harmful effects of ROS resulting from the metabolism of various chemicals or xenobiotics [40].

ROSs are naturally produced during several cellular pathways of the aerobic metabolism, including oxidative phosphorylation, electron transport 
chains in mitochondria and microsomes, the activity of oxidoreductase enzymes, which produce ROS as intermediates or final products, and even immunological reactions, such as active phagocytosis [41].

SOD and CAT enzymes have related functions [42]. SOD is a group of metalloenzymes that plays a crucial antioxidant role and constitutes the primary defense against the toxic effects of superoxide radicals in aerobic organisms. SOD catalyzes the transformation of superoxide radicals to hydrogen peroxide and water and is the first enzyme to cope with oxyradicals [43]. CAT is an enzyme that is located in the peroxisomes and facilitates the removal of hydrogen peroxide, which is metabolized to molecular oxygen and water [44]. Nwani et al. [45] assessed the alteration in LPO and antioxidant enzymes activities. They found that induction of oxidative stress in the blood and gill cells were evidenced by increased LPO level while antioxidants, namely, SOD and CAT responded in a concentration-dependent manner.

In the present work, the SOD and CAT activities increased after exposure of $C$. gariepinus to Roundup and/or Stomp. The increase in these enzyme activities is most likely a response to the increased ROS generation induced by pesticide toxicity [46]. This hypothesis was corroborated by Monteiro et al. [42], who described the simultaneous induction of SOD and CAT activities in Brycon cephalus exposed to methyl parathion and Pieniazek et al. [47], who found an increment in CAT levels in human erythrocytes after exposure to glyphosate and Roundup. The increases in the serum SOD and CAT activities that were observed in this study may be meant to neutralize the overproduction of superoxide anions and hydrogen peroxides due to the oxidative stress induced by herbicides. Our findings supported by a previous observation of Noori [48], who mentioned that the failure in the neutralization events of oxidative status results in oxidative stress which leads to the cell death by LPO.

Reduced GSH is a main non-protein thiol and is a primary reductant in cells [49]. The main role of GSH is based on its ability to protect cells against oxidative damage caused by free radicals by providing a reduced medium to cells; GSH also serves as an important substrate for the reductive detoxification of reactive intermediates such as hydrogen peroxide or hydroperoxides. Consequently, estimation of the level of this compound should provide essential data describing the processes which happen in cells [50]. In the current study, the GSH level was significantly decreased in the Roundup and/or Stomp exposed fish. This result was in accordance with those obtained by Danion et al. [51] in Oncorhynchus mykiss exposed to pendimethalin and also with previous studies, which reported a GSH depletion with other pesticides and herbicides in different cellular populations in vitro [50,52] and in vivo [53] but were opposed to others $[54,55]$. The decrease in GSH content may be related to utilization of this antioxidant in the metabolism of herbicides through GSH-Px activity. The action of this enzyme was strictly linked with the GSH concentration because it catalyzed the reaction between GSH and hydrogen peroxide, resulting in the formation of GSH disulfide. Thus, it could be assumed that herbicides, by lowering the level of GSH and decreasing the GSSG-Red activity, led to an oxidative imbalance and induced oxidative processes.

GSTs are a group of enzymes that catalyze the conjugation of reduced GSH with a variety of electrophilic metabolites and are involved in the detoxification of both reactive intermediates and oxygen radicals [44]. It has been demonstrated that the activity of these enzymes may be enhanced in the liver of fish exposed to a variety of pollutants, and even low-level organic contamination can lead to increased hepatic GST activity in fish [56]. However, in the present work, $C$. gariepinus exposed to the herbicides Roundup and Stomp showed decrease in GST activity.

This decrease may reinforce the idea of the presence of oxidants that would lead to the inactivation of the enzymatic activity [57] considering that GST is sensitive to products of the Haber-Weiss reaction [58]. The inhibition of GST was also observed in the liver of goldfish after $96 \mathrm{~h}$ exposure to Roundup [6]. Conversely, when Prochilodus lineatus was exposed to Roundup [59] found a significant increase in liver GST after 24 and $96 \mathrm{~h}$ exposure.

GPx catalyzes the reduction of hydrogen peroxide and lipid peroxides and is considered an efficient protective enzyme against LPO at the expense of GSH [60]. In this work, our result revealed a significant elevation in GPX activity in serum of C. gariepinus exposed to Roundup and/or Stomp. This increase is in consistence with that result obtained by Gehin et al. [61] in HaCaT cultured cells exposed to glyphosate or Roundup. This increase may indicate that the antioxidant pathway was stimulated, probably due to the increased production of peroxides. Although this enzyme acts principally in the removal of organic peroxides, it is also involved in the metabolization of hydrogen peroxide [62]. The aforementioned results of our study concerning immunotoxicity and oxidative stress came in harmony with histopathological changes in the liver after exposure to Roundup, which revealed severe congestion in hepatoportal blood vessels, multifocal areas of coagulative necrosis invaded with numerous leukocytes and erythrocytes and severe hydropic degeneration and macrovesicular steatosis were detected. This result was nearly similar to that found in Piaractus mesopotamicus [63] and P. lineatus [64]. In this work, the most frequent encountered types of degenerative changes are those of hydropic degeneration, cloudy swelling, vacuolization, and focal necrosis. The liver of the exposed fish had slightly vacuolated cells showing evidence of fatty degeneration. Necrosis of some portions of the liver tissue that were observed probably resulted from the excessive work required by the fish to get rid of 
the toxicant from its body during the process of detoxification by the liver. The inability of fish to regenerate new liver cells may also have led to necrosis [65].

While the liver of $C$. gariepinus exposed to Stomp showed moderate congestion, severe hydropic degeneration, and vacuolation in the hepatocytes. The portal areas revealed periductal fibrosis and round cells infiltration besides hyalinization in the wall of blood vessels. This result parallel to findings of Nabela et al. [66], who reported that these changes may be attributed by the enterohepatic pathway of the Stomp (pendimethalin-based herbicide).

\section{Conclusion}

The current study implicated that using Roundup and Stomp separately caused significant deleterious effects on aquatic vertebrates. However, the use of their combination exaggerated their obvious toxic effects. In turn, their toxicity can end up in humans through the food chain. The suitable controlled and regular use of herbicides is recommended, to obtain the beneficial effects of these resources without polluting the environment and without leaving their residues in food and water sources with potentially negative effects on human health.

\section{Authors' Contributions}

GGM, FES, and AHAH generated the concept and designed the study. GGM and WME carried out the practical part and drafted the manuscript. GGM revised and approved the final manuscript.

\section{Acknowledgments}

This work is supported by the Department of Forensic Medicine and Toxicology, Faculty of Veterinary Medicine, Zagazig University, Egypt. Furthermore, authors thank Professor Dr. Mohammed Hamed Mohammed, Professor of Pathology, Faculty of Veterinary Medicine, Zagazig University, for his help in examining the histopathological study. This work was done on authors' expense without funding from any organization.

\section{Competing Interests} interests.

The authors declare that they have no competing

\section{References}

1. Diez, M.C. (2010) Biological aspects involved in the degradation of organic pollutants. J. Soil Sci. Plant Nutr., 10: 244-267.

2. Glusczak, L., Loro, V.L., Pretto, A., Moraes, B.S., Raabe, A., Duarte, M.F., da Fonseca, M.B., de Menezes, C.C. and Valladao, D.M.D. (2011) Acute exposure to glyphosate herbicide affects oxidative parameters in Piava (Leporinus obtusidens). Arch. Environ. Contam. Toxicol., 61: 624-630.

3. Rossi, S.C., da Silva, M.D., Piancini, L.D.S., Ribeiro, C.A.O., Cestari, M.M. and de Assis, H.C.S. (2011) Sublethal effects of waterborne herbicides in tropical freshwater fish. Bull. Environ. Contam. Toxicol., 87: 603-607.

4. Stara, A., Kristan, J., Zuskova, E. and Velisek, J. (2013) Effect of chronic exposure to prometryne on oxidative stress and antioxidant response in common carp (Cyprinus carpio L.). Pestic. Biochem. Physiol., 105: 18-23.

5. Wagenhoff, A., Townsend, C.R., Phillips, N. and Matthaei, C.D. (2011) Subsidy-stress and multiple-stressor effects along gradients of deposited fine sediment and dissolved nutrients in a regional set of streams and rivers. Freshw. Biol., 56: 1916-1936.

6. Lushchak, O.V., Kubrak, O.I., Storey, J.M., Storey, K.B. and Lushchak, O.I. (2009) Low toxic herbicide Roundup induces mild oxidative stress in goldfish tissues. Chemosphere, 76: 932-937.

7. EPA, (Environmental Protection Agency). (2011) Pesticides industry sales and usage: 2006 and 2007 market estimates. In: Grube, A., Donaldson, D., Kiely, T. and Wu, L., editors. Biological and Economic Analysis Division, Office of Pesticide Programs, Office of Chemical Safety and Pollution Prevention. U.S. Environmental Protection Agency, Washington, DC, USA.

8. Romero, D.M., de Molina, M.C.R. and Juarez, A.B. (2011) Oxidative stress induced by a commercial glyphosate formulation in a tolerant strain of Chlorella kessleri. Ecotoxicol. Environ. Saf., 74: 741-747.

9. Jiraungkoorskul, W., Upatham, E.S., Kruatrachue, M., Sahaphong, S., Vichasri-Grams, S. and Pokethitiyook, P. (2002) Histopathological effects of Roundup, a glyphosate herbicide, on Nile tilapia (Oreochromis niloticus). ScienceAsia, 28: 121-127.

10. Fetvadjieva, N., Straka, F., Michailova, P., Balinov, I., Lubenov, I., Balinova, A., Pelov, V., Karsova, V. and Tsvetkov, D. (1994) In: Fetvadjieva, N., editor. Handbook of Pesticides. $2^{\text {nd }}$ Revised. Zemizdat Inc., Sofia. p330.

11. Meister, R.T., editor. (1992) Farm Chemicals Handbook '92. Meister Publishing Company, Willoughby, Ohio, USA. p197-202.

12. Lushchak, V.I. (2011) Environmentally induced oxidative stress in aquatic animals. Aquat. Toxicol., 101: 13-30.

13. Perez, J., Domingues, I., Monteiro, M., Soares, A.M. and Loureiro, S. (3013) Synergistic effects caused by atrazine and terbuthylazine on chlorpyrifos toxicity to early - Life stages of the zebrafish Danio rario. Environ. Sci. Pollut. Res., 20: 4671-4680.

14. Dabas, A., Nagpure, N.S., Kumar, R., Kushwaha, B., Kumar, P. and Lakra W. (2012) Assemment of tissue-specific effect of cadmium on antioxidant defense system and lipid peroxidation in freshwater murrel, Channa punctatus. Fish Physiol. Biochem., 38: 468-482.

15. Abdelghani, A.A., Tchounwou, P.B., Anderson, A.C., Sujono, H., Heyer, L.R. and Monkiedje, A. (1997) Toxicity evaluation of single and chemical mixtures of Roundup, Garlon-3A, 2,4-D, and synthetic detergent surfactant to channel catfish (Ictalurus punctatus), bluegill sunfish (Lepomis microchirus), and crawfish (Procambarus spp.). Environ. Toxicol. Water, 12: 237-243.

16. Kidd, H. and James, D.R. (1991) The Agrochemicals Handbook. $3^{\text {rd }}$ ed. Royal Society of Chemistry Information Services, Cambridge, UK. p3-11.

17. USEPA, (United State Environmental Protection Agency). (1987) Pesticide Tolerance for Pendimethalin. Fed. Regist. 52: 47734.5. Dec. 16-1987. USEPA, Washington, DC, USA. p10-117.

18. Lucky, Z. (1977) Methods for the Diagnosis of Fish Diseases. $1^{\text {st }}$ ed. Amerind Publishing Co., Pvt., Ltd., New Delhi, Bombay, Calcutta and New York. p140.

19. Cruickshank, R., Duguid, R., Marmion, B.P. and Swain, R.A. (1975) Natural and acquired immunity in: Medical microbiology. In: Cruickshank, R. and Swain, R.A., editors. Microbiology; Infection and Immunology. Vol. 1. Part 1. Churchill Livingstone, Edinburgh and London. p137.

20. Wilkinson, P.C. (1977) In: Thompson, R.A., editor. Techniques in Clinical Immunology. Oxford Blackwell Publication, USA. p201-212. 
21. Lucy, F.I. and Larry, D.B. (1982) Ontageny and line differences in mitogenic responces of chicken lymphocyte. Poult. Sci., 62: 579-584.

22. Misra, H. and Fridivich, I. (1972) Role of superoxide anion in autooxidation of epinephrine, simple assay for SOD. J. Biochem., 247: 3170-3175.

23. Packer, L. and Glazer, A.N. (1990) Method in enzymology. Oxygen Radicals in Biological Systems, Part B; Oxygen Radicals and Antioxidants. Vol. 186. Academic Press Inc., New York. p355-367.

24. Sinha, A.K. (1972) Colorimetric assay of catalase. Analytical Biochemistry, 47, 389 p251.

25. Beutler, E. (1957) Glutathione instability of drug - Sensitive red cells; A new method for the in vitro detection of drug sensitivity. J. Lab. Clin. Med., 49: 84-95.

26. Beutler, E., Duron, O. and Kelly, B.M. (1963) Improved method for the determination of blood glutathione. J. Lab. Clin. Med., 61: 822-888.

27. Habig, W.H., Pabst, M.J. and Jacoby, W.B. (1974) Glutathione S-transferases. The first enzymatic step in mercapturic acid formation. J. Biol. Chem. 249: 7130-7139.

28. Puertas, M.C., Martos, J.M.M., Cobo, M.P., Carrera, M.D. and Exposito, M.J.R. (2012) Plasma oxidative stress parameters in men and women with early stage Alzheimer type dementia. Exp. Gerontol., 47: 625-630.

29. Suvarna, S.K., Layton, C. and Bancroft, J.D. (2013) Bancroft's Theory and Practice of Histological Techniques. $7^{\text {th }}$ ed. Churchill Livingstone, Elsevier, England.

30. Sandrini, J.Z., Rola, R.C., Lopes, F.M., Buffon, H.F., Freitas, M.M., Martins, C.M.G. and Rosa, C.E. (2013) Effects of glyphosate on cholinesterase activity of the mussel Pernaperna and the fish Danio rerio and Jenynsia multidentata: In vitro studies. Aquat. Toxicol., 130: 171-173.

31. Betoulle, S., Duchiron, C. and Deschaux, P. (2000) Lindane differently modulates intracellular calcium levels in two populations of rainbow trout (Oncorhynchus mykiss) immune cells: Head kidney phagocytes and peripheral blood leucocytes. Toxicology, 145: 203-215.

32. Harikrishnan, R., Balasundaram, C., Kim, M.C., Kim, J.S., Han, Y.J. and Heo, M.S. (2009) Innate immune response and disease resistance in Carassius auratus by triherbal solvent extracts. Fish Shellfish Immunol., 27: 508-515.

33. Galloway, T.S. and Depledge, M.H. (2001) Immunotoxicity in invertebrates, measurement and ecotoxicological relevance. Ecotoxicology, 10: 5-23.

34. Kreutz, L.C., Barcellos, L.J.G., Valle, S.F., Silva, T.O., Anziliero, D., Santos, E.D., Pivato, M. and Zanatta, R. (2011) Altered hematological and immunological parameters in silver catfish (Rhamdia quelen) following short term exposure to sublethal concentration of glyphosate. Fish Shellfish Immunol., 30: 51-57.

35. Danion, M., Le Floch, S., Kanan, R., Lamour, F. and Quentel, C. (2012) Effects of in vivo chronic exposure to pendimethalin/Prowl $400^{\circledR}$ on sanitary status and the immune system in rainbow trout (Oncorhynchus mykiss). Sci. Total Environ., 424: 143-152.

36. Camus, L., Jones, M., Børseth, J., Grøsvik, B., Regoli, F. and Depledge, M. (2002) Total oxyradical scavenging capacity and cell membrane stability of haemocytes of the Arctic scallop, Chlamys islandicus, following benzo(a)pyrene exposure. Mar. Environ. Res., 54: 425-430.

37. Mohamed, A.H. (2011) Sublethal toxicity of Roundup to immunological and molecular aspects of Biomphalaria alexandrina to Schistosoma mansoni infection. Ecotoxicol. Environ. Saf., 74: 754-760.

38. Matricon-Gondran, M. and Letocart, M. (1999) Internal defenses of the snail Biompha-laria glabrata I. Characterization of hemocytes and fixed phagocytosis. J. Invertebr. Pathol., 74: 224-234.

39. Ortiz-Ordonez, E., Uria-Galicia, E., Ruiz-Picos, R.A., Duran, A.G.S., Trejo, Y.H., Sedeno-Diaz, J.E. and LopezLopez, E. (2011) Effect of Yerbimat herbicide on lipid peroxidation, catalase activity, and histological damage in gills and liver of the freshwater fish Goodea atripinnis. Arch. Environ. Contam. Toxicol., 61: 443-452.

40. Blahová, J., Plhalová, L., Hostovský, M., Divišov, L., Dobšíková, R., Mikulíková, I., Štěpánová, S. and Svobodová, Z. (2013) Oxidative stress responses in zebrafish Danio rerio after subchronic exposure to atrazine. Food Chem. Toxicol., 61: 82-85.

41. Regoli, F. and Giuliani, M.E. (2014) Oxidative pathways of chemical toxicity and oxidative stress biomarkers in marine organisms. Mar. Environ. Res., 93: 106-117.

42. Monteiro, D.A., de Almeida, J.A., Rantin, F.T. and Kalinin, A.L. (2006) Oxidative stress biomarkers in the freshwater characid fish, Brycon cephalus, exposed to organophosphorus insecticide Folisuper 600 (methyl parathion). Comp. Biochem. Phys. C., 143: 141-149.

43. Kohen, R. and Nyska, A. (2002) Oxidation of biological systems: Oxidative stress phenomena, antioxidants, redox reactions, and methods for their quantification. Toxicol. Pathol., 30: 620-650.

44. Van der Oost, R., Beyer, J. and Vermeulen, N.P. (2003) Fish bioaccumulation and biomarkers in environmental risk assessment: A review. Environ. Toxicol. Pharmacol., 13: $57-149$.

45. Nwani, C.D., Nagpure, N.S., Kumar, R., Kushwaha, B. and Lakra, W.S. (2013) DNA damage and oxidative stress modulatory effects of glyphosate-based herbicide in freshwater fish, Channa punctatus. Environ. Toxicol. Pharmacol., 36: 539-547.

46. John, S., Kale, M., Rathore, N. and Bhatnagar, D. (2001) Protective effect of vitamin $\mathrm{E}$ in dimethoate and malathion induced oxidative stress in rat erythrocytes. J. Nutr. Biochem., 12: 500-504.

47. Pieniazek, D., Bukowska, B. and Duda, W. (2004) Comparison of the effect of Roundup Ultra 360 SL pesticide and its active compound glyphosate on human erythrocytes. Pestic. Biochem. Physiol., 79: 27-34.

48. Noori, S. (2012) An overview of oxidative stress and antioxidant defensive system. Scientific Reports, 1:413.

49. Yilmaz, S., Atessahin, A., Sahna, E., Karahan, I. and Ozer, S. (2006) Protective effect of lycopene on adriamycin-induced cardiotoxicity and nephrotoxicity. Toxicology, 218: 164-171.

50. Bukowska, B. (2003) Effects of 2,4-d and its metabolite 2,4-dichlorophenol on antioxidant enzymes and level of glutathione in human erythrocytes. Comp. Biochem. Physiol. C., 135: 435-441.

51. Danion, M., Le Floch, S., Lamour, F. and Quentel, C. (2014) Effects of in vivo chronic exposure to pendimethalin on EROD activity and antioxidant defenses in rainbow trout (Oncorhynchus mykiss). Ecotoxicol. Environ. Saf., 99: 21-27.

52. Cereser, C., Boget, S., Parvaz, P. and Revol, A. (2001) Thiram-induced cytotoxic-ity is accompanied by a rapid and drastic oxidation of reduced glutathione with consecutive lipid peroxidation and cell death. Toxicology, 163: 153-162.

53. Banerjee, B.D., Seth, V., Bhattacharya, A., Pasha, S.T. and Chakraborty, A.K. (1999) Biochemical effects of some pesticides on lipid peroxidation and free-radical scavengers. Toxicol. Lett., 107: 33-47.

54. Slaughter, M.R., Thakkar, H. and O'Brien, P.J. (2002) Effect of diquat on the antioxidant system and cell growth in human neuroblastoma cells. Toxicol. Appl. Pharmacol., 178: 63-70.

55. Tsukamoto, M., Tampo, Y., Sawada, M. and Yonaha, M. (2002) Paraquat induced oxidative stress and dysfunction of the glutathione redox cycle in pulmonary microvascular endothelial cells. Toxicol. Appl. Pharmacol., 178: 82-92.

56. Machala, M., Petřivalský, M., Nezveda, K., Ulrico, R., Dušek, L., Piačka, V. and Svobodová, Z. (1997) Responses of carp hepatopancreatic 7-ethoxyresorufin-O-deethylase and glutathione-dependent enzymes to organic pollutants - A 
field study. Environ. Toxicol. Chem., 16: 1410-1416.

57. Bagnyukova, T.V., Chahrak, O.I. and Lushchak, V.I. (2006) Coordinated response of goldfish antioxidant defenses to environmental stress. Aquat. Toxicol., 78: 325-331.

58. Hermes-Lima, M. and Storey, K.B. (1993) In vitro oxidative inactivation of glutathione S-transferase from a freeze tolerant reptile. Mol. Cell. Biochem., 124: 149-158.

59. Modesto, K.A. and Martinez, C.B.R. (2010) Roundup causes oxidative stress in liver and inhibits acetylcholinesterase in muscle and brain of the fish Prochilodus lineatus. Chemosphere, 78: 294-299.

60. Moreno, I., Pichardo, S., Góomez-Amores, L., Mate, A., Vazquez, C.M. and Cameán, A.M. (2005) Antioxidant enzyme activity and lipid peroxidation in liver and kidney of rats exposed to microcystin- $L R$ administered intraperitoneally. Toxicon, 45: 395-402.

61. Gehin, A., Guyon, C. and Nicod, L. (2006) Glyphosateinduced antioxidant imbalance in HaCaT: The protective effect of vitamins C and E. Environ. Toxicol. Pharmacol., 22: 27-34.
62. Maran, E., Fernández, M., Barbieri, P., Font, G. and Ruiz, M.J. (2009) Effects of four carbamate compounds on antioxidant parameters. Ecotoxicol. Environ. Saf., 72: 922-930.

63. Shiogiri, N.S., Paulino, M.G., Carraschi, S.P., Baraldi, F.G., Cruz, C. and Fernandes, M.N. (2012) Acute exposure of a glyphosate-based herbicide affects the gills and liver of the neotropical fish, Piaractus mesopotamicus. Environ. Toxicol. Pharmacol., 2: 388-496.

64. Langiano, V.C. and Martinez, C.B. (2008) Toxicity and effects of a glyphosate-based herbicide on the neotropical fish Prochilodus lineatus. Comp. Biochem. Physiol. C., 147: 222-231.

65. Abd-Algadir, M.I., Elkhier, M.K.S. and Idris, O.F. (2011) Changes of fish liver (Tilapia nilotica) made by herbicide (Pendimethalin). J. Appl. Biosci., 43: 2942-2946.

66. Nabela, I.E., Reda, R.M. and El-Araby, I.E. (2011) Assessment of Stomp ${ }^{\circledR}$ (Pendimethalin) toxicity on Oreochromis niloticus. J. Am. Sci., 7: 568-576. 